\title{
Performance of microscopy and RDTs in the context of a malaria prevalence survey in Angola: a comparison using PCR as the gold standard
}

\author{
Cláudia Fançony $^{1 *}$, Yuri V Sebastião ${ }^{1,2}$, João E Pires ${ }^{1,3}$, Dina Gamboa ${ }^{1,4}$ and Susana V Nery ${ }^{1,5^{*}}$
}

\begin{abstract}
Background: Accurate identification of Plasmodium infections in community surveys is essential to successful malaria control. Microscopy and rapid diagnostic tests (RDTs) are the main techniques used to diagnose malaria in field-based surveys. While microscopy is still considered the gold standard, RDTs are growing in popularity as they allow for rapid and inexpensive diagnosis. Using data from a prevalence survey conducted in north-western Angola in 2010, the authors aimed to compare the performance of microscopy and RDTs in identifying Plasmodium falciparum infections, using polymerase chain reaction (PCR) as the gold standard.
\end{abstract}

Methods: Results from 3,307 subjects (1,225 preschool-aged children (zero to five year olds), 1,134 school-aged children (six to 15 year olds) and 948 mothers/caregivers (>15 years of age)), tested for $P$. falciparum infections, were utilized. The sensitivity, specificity, positive, and negative predictive values (PPV and NPV) of microscopy and Paracheck-Pfø were compared using the McNemar's test and the weighted generalized score Chi-squared test for paired data.

Results: The prevalence of $P$. falciparum infections determined by PCR and microscopy was $15.9 \%$ and by Paracheck- Pf was $16.3 \%$. Compared to microscopy, Paracheck-Pfø had significantly higher sensitivity (72.8\% versus $60 \%)$, specificity (94.3\% versus $92.5 \%)$, PPV (70.7\% versus $60 \%$ ) and NPV (94.8\% versus $92.5 \%)$. Both tests had significantly lower sensitivity in mothers (36.8\% for microscopy and $43.7 \%$ for Paracheck-Pf $)$ than in their children (68.4\% in zero to five years-old and $60.6 \%$ in six to 15 years-old for microscopy and $80.4 \%$ in zero to five year-olds and $76.5 \%$ in six to 15 year-olds for Paracheck-Pfø).

Conclusion: Both microscopy and RDTs performed suboptimally when compared to PCR. False negativity could be associated with the low parasite density profile of the samples. False positivity may be related to the well-described limitations of those techniques such as level of expertise of microscopists or persistent antigenicity from previous infections in the case of RDTs. Nevertheless, RDTs had enhanced performance comparatively to microscopy in detecting malaria infections, favouring their use in community cross-sectional malaria surveys, where expert performance of microscopy is hard to accomplish.

Keywords: PCR, RDT, Microscopy, Malaria, Plasmodium

\section{Background}

Active surveillance through field-based surveys is considered a powerful tool for estimating the burden of malaria, as it identifies sustained foci of transmission perpetuated by asymptomatic carriers and low parasitaemia infections [1-3]. Accurate diagnosis of Plasmodium infections is

* Correspondence: cisa.cfv@gmail.com; s.nery@uq.edu.au

${ }^{1}$ CISA Project-Health Research Centre in Angola, Caxito, Angola

${ }^{5}$ The University of Queensland, Infectious Disease Epidemiology Unit, School

of Population Health, Herston, Queensland, Australia

Full list of author information is available at the end of the article crucial for providing realistic estimates of the burden of malaria and preventing misinformed interventions $[4,5]$.

Microscopy has been the method of choice in determining the prevalence of malaria in epidemiologic surveys, allowing quantification and differentiation of Plasmodium species at low cost [6-8]. More recently, rapid diagnostic tests (RDTs) were introduced as screening tools in fieldbased surveys, as they provide readily available results allowing for treatment in situ [6,9,10]. RDTs alone were used to monitor Plasmodium infections in malaria 
surveillance programmes in Tanzania, Gambia, Bangladesh and in the 2006-2007 malaria indicator survey in Angola [11-14].

The choice between microscopy and RDTs is not always clear-cut as the performance of both diagnostic techniques in operational conditions varies depending on transmission intensity, prevalence of infections, and parasite density [5,15-17]. Microscopy is reported to detect about $75 \%$ of malaria infections in high transmission areas, whereas in low transmission areas this method has been reported to miss up to $88 \%$ of infections [17]. Furthermore, the level of expertise of technicians, quality of the equipment, and workload may lead to inaccurate estimates of parasite density and species differentiation $[4,7]$. On the other hand, the performance of HRP2immunochromatography-based RDTs is affected by the detection of persistent antigenicity from previous infections, which leads to false positives and overestimate prevalence [10,18-20]. Moreover, deletions or mutations within the $p f h r p-2$ gene and the prozone effect may lead to false negatives [21-25]. Additionally, sensitivity of RDTs can vary due to their vulnerability to extreme temperature and high humidity occurring in field-based surveys [26]. Considering these limitations, the use of RDTs in malaria surveys is only advisable when used in comparison with microscopy, as recommended by WHO and performed in the majority of studies $[9,10,18,27-29]$. However, reliance on microscopy to measure the performance of RDTs should be approached with caution as this technique itself can be compromised by the limitations described above [1,30-32]. Alternatively, PCR is highly sensitive, detecting low parasitaemia cases missed by other techniques and easily reproducible [33-37]. Nevertheless, it is also highly expensive, time and labour consuming and therefore used in only a few studies for confirmation of prevalence data and to measure the accuracy of microscopy and RDTs [31,38-40].

Using data from a prevalence survey conducted in north-west Angola, this study compared the performance (assessed by sensitivity, specificity, positive, and negative predictive values (PPV and NPV)), of microscopy and Paracheck-Pf in the detection of Plasmodium falciparum infections, using PCR as the gold standard.

\section{Methods}

\section{Study area}

The study was conducted in Bengo province, northwestern Angola, in the Health and Demographic Surveillance System (HDSS) study area covered by the CISA project (Health Research Centre in Angola, translated) [41]. This is considered a meso-endemic malaria area with stable transmission intensity [42]. The main peak of malaria occurs in the rainy season, between November and May [11]. A recent study from the same geographical area reported that $97 \%$ of malaria infections are due to $P$. falciparum but all other human species are present either alone or in mixed infections. Almost $90 \%$ of malaria infections are due to $P$. falciparum alone, $6.5 \%$ to $P$. falciparum and $P$. malariae together, $3.7 \%$ due to $P$. ovale curtisi or $P$. ovale wallikeri alone or in combination with other species and $1.1 \%$ due to $P$. vivax alone [43].

\section{Sample collection}

Finger-prick blood samples for microscopy, Paracheck$\mathrm{Pf}^{\circ}$ and $\mathrm{PCR}$ were collected from children and their mothers/caregivers, during a baseline field-based prevalence survey implemented between May and August 2010, as described by Sousa-Figueiredo et al. [6]. Of the 3,339 participants initially enrolled in the survey, 3,307 (1,225 preschool-aged children (zero to five year olds), 1,134 school-aged children (six to 15 year olds) and 948 mothers/caregivers ( $>15$ years of age), were tested by the three techniques and included in the present study. No clinical assessment of the participants was done at the time of recruitment.

\section{Team training}

The laboratory diagnosis team was composed of five technicians with pre-university training and previous work experience in public and private health units. A five-day retraining course was provided by the CISA project resident laboratory experts and included theoretical and practical sessions on: finger prick blood collection, thick and thin blood smear preparation, Giemsa staining and slide reading, following standard operational procedures, according to the Basic Laboratory Methods in Medical Parasitology manual from WHO [44]. Field workers and microscopists were also trained on how to perform and read Paracheck-Pf. All laboratory technicians were supplied with an operational procedures manual regarding laboratory and field diagnosis.

\section{Microscopy}

Thick and thin blood smears were made on the same slide, air dried and transported to the CISA laboratory where they were stored. The slides were stained with 10\% Giemsa for 15 minutes and screened for P. falciparum parasites by two independent technicians (doubleblind). Discordance in the diagnostic (positivity/negativity) was solved by a third reader and discordance in parasite counts was solved by calculating the mean of the two readings. The agreement between the two laboratory technicians performing the 2 independent readings was 99.9\%, Kappa $=0.997, \mathrm{P}<0.001$. Assexual parasitaemia was quantified against 200 to 500 leucocytes, assuming a white blood cell count of $8,000 / \mu \mathrm{l}$ as recommended by WHO [45]. A slide was considered negative if no parasite was seen when 500 leucocytes were counted. Quality control 
readings were performed in randomly selected samples by experienced CISA researchers.

\section{Paracheck-Pf ${ }^{\oplus}$}

The Paracheck-Pf test was performed accordingly to the manufacturer (Orchid Biomedical Systems, India).

PCR assay (nested PCR for RNA (SSU-rRNA) amplification) Blood samples were spotted onto Whatman $3 \mathrm{MMChr}^{\circ}$ filter paper, air dried and stored at $4^{\circ} \mathrm{C}$ in the CISA laboratory until DNA extraction. Total DNA was extracted using the QIAmp DNA Mini Kit (QIAGEN, UK), following the manufacturer's instructions. Nested PCR was performed using primers complementary to the Plasmodium small subunit ribosomal RNA (SSU-rRNA) gene, as described previously [35,46] and in detail by Fançony [43].

\section{Statistical analysis}

Data were analysed using $\mathrm{SAS}^{\circ}$ software version 9.3. Sensitivity, specificity, positive, and negative predictive values (PPV and NPV) of microscopy and Paracheck-Pf ${ }^{\circ}$, with PCR as the gold standard, were determined using $2 \times 2$ contingency tables and compared using the McNemar's test (sensitivity and specificity) or the weighted generalized score Chi-squared test (PPV and NPV) for paired data [47]. Exact $95 \%$ confidence intervals $\left(\mathrm{Cl}_{95}\right)$ were calculated for each measure listed above. For each of the two diagnostic techniques, the Pearson Chi-squared test was used to assess difference in sensitivity, specificity, and predictive values across the three age groups. Statistical significance was set at $\mathrm{p}<0.05$.

\section{Ethics approval}

Ethical approval was obtained from the Angolan Ministry of Health Ethics Committee. Written informed consent was obtained before inclusion in the study and antimalarial treatment with ACTs was provided by a nurse or physician when participants had a positive rapid test result. Participants who mentioned feeling unwell were advised to go to the nearest health centre; those deemed with a serious illness were observed by the physician on site if present or transported by the research team to the reference hospital.

\section{Results}

Table 1 provides a matched-sample description of how microscopy and Paracheck-Pf performed in relation to PCR as the gold standard. In 3,307 samples screened, 525 (15.9\%) were identified as positive P. falciparum infections by PCR and microscopy and $540(16.3 \%)$ by Paracheck-Pf ${ }^{\circ}$.

In direct comparison to microscopy, Paracheck-Pf had significantly higher sensitivity, specificity and predictive values (Table 2). Microscopy correctly identified 315 out of 525 PCR-positive $P$. falciparum infections $(60.0 \%$ sensitivity, $\mathrm{CI}_{95:}$ :55.8-64.2) and 2,572 out of 2,782 PCR-negative samples (92.5\% specificity, $\mathrm{CI}_{95:}$ 91.4-93.4), with a PPV of $60.0 \%$ and NPV of $92.5 \%$. Paracheck-Pf correctly identified 382 out of 525 PCR-positive P. falciparum infections (72.8\% sensitivity, $\mathrm{CI}_{95:}$ : 68.7-76.5) and 2,624 out of 2,782 PCR-negative samples (94.3\% specificity, $\mathrm{CI}_{95:}$ 93.4-95.2), with a PPV of $70.7 \%$ and NPV of $94.8 \%$ (Table 2).

Table 3 shows how, for each diagnostic test, the measures of performance varied across the different age groups. The sensitivity of microscopy was lower in mothers (36.8\%, $\mathrm{Cl}_{95:}$ 26.7-47.8) than in their children $\left(68.4 \%, \mathrm{Cl}_{95}\right.$ : 61.9-74.5, in zero to five year-olds and $60.6 \%, \mathrm{CI}_{95}$ : 53.7 67.2 , in six to 15 year-olds) ( $<<0.0001)$. No significant change in the specificity of microscopy was observed across the three age groups. Similarly, the sensitivity of Paracheck-Pf ${ }^{\circ}$ was lower in mothers $\left(43.7 \%, \mathrm{CI}_{95}\right.$ : 33.1$54.7)$ than in their children $\left(80.4 \%, \mathrm{CI}_{95:} 74.7-85.4\right.$, in zero to five year-olds and $76.5 \%, \mathrm{CI}_{95}: 70.3-82.1$, in six to 15 year-olds) $(\mathrm{p}<0.0001)$ (Table 3$)$.

\section{Discussion}

In this study, the prevalence values determined by microscopy, RDTs and PCR were similar. However, compared to $\mathrm{PCR}$ as the gold standard, microscopy and Paracheck-Pf detected only 60.0 and $72.8 \%$ of the true $P$. falciparum infections, respectively. In line with previous studies, parasite density might have determined the low proportion of positive infections detected by microscopy and RDT [17]. As discussed by Sousa-Figueiredo and colleagues, parasite density ranged from moderate to low, decreasing with older age [6]. Accordingly, the present study found that sensitivity of microscopy and RDTs decreased with older

Table 1 Matched-sample description of the data

\begin{tabular}{|c|c|c|c|c|c|c|}
\hline \multirow[b]{2}{*}{ Microscopy } & \multicolumn{3}{|c|}{ PCR positive } & \multicolumn{3}{|c|}{ PCR negative } \\
\hline & Paracheck-Pf ${ }^{\oplus}$ & Paracheck-Pf & Total & Paracheck-Pf & Paracheck-Pf ${ }^{\oplus}$ & Total \\
\hline & Positive & Negative & & Positive & Negative & \\
\hline Positive & 297 & 18 & 315 & 96 & 114 & 210 \\
\hline Negative & 85 & 125 & 210 & 62 & 2,510 & 2,572 \\
\hline Total & 382 & 143 & 525 & 158 & 2,624 & 2,782 \\
\hline
\end{tabular}


Table 2 Sensitivity, specificity, predictive values of microscopy and Paracheck- Pf ${ }^{\oplus}$ with PCR as gold standard

\begin{tabular}{|c|c|c|c|c|c|c|c|}
\hline & & $\begin{array}{c}\text { PCR } \\
\text { Positive } \\
(n=525)\end{array}$ & $\begin{array}{c}\text { PCR } \\
\text { Negative } \\
(n=2,782)\end{array}$ & $\begin{array}{c}\text { Sensitivity \% } \\
\left(\mathrm{Cl}_{95}\right)\end{array}$ & $\begin{array}{c}\text { Specificity \% } \\
\left(\mathrm{Cl}_{95}\right)\end{array}$ & $\begin{array}{l}\text { PPV \% } \\
\left(\mathrm{Cl}_{95}\right)\end{array}$ & $\begin{array}{l}\text { NPV \% } \\
\left(\mathrm{Cl}_{95}\right)\end{array}$ \\
\hline \multirow[t]{4}{*}{ Microscopy } & Positive & 315 & 210 & 60.0 & 92.5 & 60.0 & 92.5 \\
\hline & $(n=525)$ & & & $(55.8-64.2)$ & $(91.4-93.4)$ & $(55.7-64.2)$ & (91.4-93.4) \\
\hline & Negative & 210 & 2,572 & & & & \\
\hline & $(n=2,782)$ & & & & & & \\
\hline \multirow[t]{5}{*}{ Paracheck-Pf® } & Positive & 382 & 158 & 72.8 & 94.3 & 70.7 & 94.8 \\
\hline & $(n=540)$ & & & $(68.7-76.5)$ & $(93.4-95.2)$ & $(66.7-74.6)$ & (93.9-95.6) \\
\hline & Negative & 143 & 2,624 & & & & \\
\hline & $(n=2,767)$ & & & & & & \\
\hline & & & P-value* & $<0.0001$ & $<0.0001$ & $<0.0001$ & $<0.0001$ \\
\hline
\end{tabular}

PPV: positive predictive value; NPV: negative predictive value.

$\mathrm{Cl}_{95}: 95 \%$ confidence interval.

*Obtained from McNemar test (sensitivity, specificity) / Weighted generalized score Chi-square test (PPV, NPV).

age. This is also consistent with the fact that, in malariaendemic countries, acquired immunity in adult individuals is associated with the presence of submicroscopic infections that are more likely to be undetected by field microscopy or RDTs $[5,17,48-50]$. On the other hand, false negatives found by Paracheck-Pf ${ }^{\circledast}$ may be explained by deletions or mutations within the pfhrp-2 gene or by the prozone effect reported by others [21-25,51,52]. Nevertheless, RDTs were significantly more sensitive than microscopy, probably corroborating the ability of RDTs to detect parasites below the threshold of microscopy as previously described [15,53]. Additionally, the $8 \%$ false positives detected by microscopy may be explained by erroneous readings performed by the laboratory technicians, mistakenly counting dirt, cell debris and stain artefacts as malaria parasites, whereas the false positives (6\%) incorrectly identified by Paracheck-Pf may be associated with persistent antigenicity from previous infections and with cross reactivity with autoantibodies, non-falciparum malaria and other infectious diseases [5,18,28,30,53-57]. This has resulted in similar specificity between RDTs and microscopy albeit that those from RDTs were significantly higher. Given the results of sensitivity and specificity of microscopy in this study, using it as gold standard for

Table 3 Sensitivity, specificity and predictive values of microscopy and Paracheck-Pf ${ }^{\circledR}$ by age group with PCR as gold standard

\begin{tabular}{|c|c|c|c|c|c|}
\hline & Age & $\begin{array}{c}\text { Sensitivity \% } \\
\left(\mathrm{Cl}_{95}\right)\end{array}$ & $\begin{array}{c}\text { Specificity \% } \\
\left(\mathrm{Cl}_{95}\right)\end{array}$ & $\begin{array}{l}\text { PPV \% } \\
\left(\mathrm{Cl}_{95}\right)\end{array}$ & $\begin{array}{l}\text { NPV \% } \\
\left(\mathrm{Cl}_{95}\right) \\
\end{array}$ \\
\hline \multirow[t]{6}{*}{ Microscopy } & $0-5$ & 68.4 & 92.7 & 67.8 & 92.9 \\
\hline & & $(61.9-74.5)$ & $(90.9-94.2)$ & $(61.3-73.9)$ & $(91.1-94.4)$ \\
\hline & $6-15$ & 60.6 & 91.6 & 62.6 & 91.0 \\
\hline & & $(53.7-67.2)$ & $(89.7-93.4)$ & $(55.6-69.3)$ & (88.9-92.7) \\
\hline & $>15$ & 36.8 & 93.0 & 34.8 & 93.6 \\
\hline & & $(26.7-47.8)$ & $(91.1-94.6)$ & $(25.2-45.4)$ & $(91.7-95.1)$ \\
\hline \multicolumn{2}{|l|}{ P-value* } & $<0.0001$ & 0.5032 & $<0.0001$ & 0.0897 \\
\hline \multirow[t]{6}{*}{ Paracheck- Pf ${ }^{\oplus}$} & $0-5$ & 80.4 & 93.5 & 73.6 & 95.5 \\
\hline & & $(74.7-85.4)$ & (91.8-95.0) & $(67.6-79.0)$ & $(94.0-96.7)$ \\
\hline & $6-15$ & 76.5 & 93.3 & 72.4 & 94.5 \\
\hline & & $(70.3-82.1)$ & $(91.5-94.8)$ & $(66.1-78.2)$ & $(92.8-95.9)$ \\
\hline & $>15$ & 43.7 & 96.4 & 55.1 & 94.4 \\
\hline & & $(33.1-54.7)$ & $(94.9-97.5)$ & $(42.6-67.1)$ & $(92.7-95.9)$ \\
\hline P-value* & & $<0.0001$ & 0.0064 & 0.0088 & 0.4946 \\
\hline
\end{tabular}

Age shown in years; PPV: positive predictive value; NPV: negative predictive value. 
comparison would lead to the misclassification of samples (85 positive and 118 negative) and consequently misleading evaluation of the performance of RDTs. It should be taken into account that even though laboratory technicians who participated in this study were retrained on malaria diagnosis their level of expertise was not formally assessed. Therefore further training and/or a stricter selection of technicians could have increased the performance of microscopy. Despite providing reliable epidemiologic information, the use of PCR is less feasible in studies conducted in developing countries due to the high costs involved $[1,40,58]$. A pooled PCR, reported to be economically more viable than individual PCR, would provide a feasible alternative for confirming prevalence of infections and evaluating the performance of RDTs or microscopy in determining malaria prevalence $[1,58]$.

In conclusion, given the observed higher sensitivity, specificity and predictive values of RDTs, the data presented here suggest that, for community-based surveys with similar levels of endemicity and transmission rates and where adequate expert performance of microscopy is hard to accomplish, the use of RDTs to determine the prevalence of $P$. falciparum infections is a preferable alternative, if parasite density does not need to be determined. In addition to the low cost and practicability of RDTs, the use of malaria HRP-2/pLDH (pan) combo tests would allow minimizing HRP-2 associated limitations such as false negativity, related to gene deletions or prozone effect; and false positivity associated to persistent antigenicity, extending the feasibility of their use in this context [59]. However both pLDH negative/HRP2 positive and $\mathrm{pLDH}$ positive/but HRP2 negative tests would require PCR confirmation in order to: discriminate low parasite density from persistent antigenicity, and confirm the species involved, respectively. When microscopy is the diagnostic technique chosen, thus allowing for determining parasite density, these results suggest that training microscopists and establishing adequate quality control and assurance systems should be set as priorities, in order to guarantee an expert level of microscopy [45]. A systematic review of the publications comparing the performance of different diagnostic techniques in different endemicity and transmission intensity settings is warranted so that informed guidelines regarding the detection and control of Plasmodium infections can be developed.

\section{Competing interests}

The authors declare that they have no competing interests.

\section{Authors' contributions}

SVN was responsible for the study design and coordination and contributed to drafts of the manuscript. CFV and DG carried out the PCR analysis and supervised the microscopy work and field diagnosis. CFV drafted the manuscript. YVS performed the statistical analysis and contributed to drafts of the manuscript. JEP contributed to the statistical analysis and drafts of the manuscript. All authors read and approved the final draft of the manuscript.

\section{Acknowledgements}

The authors wish to acknowledge all the researchers and technicians who supported this study, namely from the CISA Project and from the molecular biology laboratory of the Pediatric Hospital David Bernardino. We wish to thank Luis Bernardino for the molecular biology laboratory facilities, Simon Brooker for critical reading of the manuscript, the local administration and all the members of the community who participated in this study. This work was financed by the promoters of the CISA Project (Portuguese Institute for Development Assistance, Calouste Gulbenkian Foundation, Bengo Provincial Government and the Ministry of Health of Angola).

\section{Author details}

${ }^{1}$ CISA Project-Health Research Centre in Angola, Caxito, Angola. ${ }^{2}$ Department of Epidemiology \& Biostatistics, College of Public Health, University of South Florida, Tampa, FL, USA. ${ }^{3}$ Department of Internal Medicine, Hospital Professor Fernando Fonseca, Amadora, Portugal. ${ }^{4} \mathrm{Clinical}$ Pathology Laboratory of Cova da Beira Hospital, Castelo Branco, Portugal. ${ }^{5}$ The University of Queensland, Infectious Disease Epidemiology Unit, School of Population Health, Herston, Queensland, Australia.

Received: 14 May 2013 Accepted: 2 August 2013

Published: 13 August 2013

\section{References}

1. Hsiang MS, Hwang J, Kunene S, Drakeley C, Kandula D, Novotny J, Parizo J, Jensen T, Tong M, Kemere J, Dlamini S, Moonen B, Angov E, Dutta S, Ockenhouse C, Dorsey G, Greenhouse B: Surveillance for malaria elimination in Swaziland: a national cross-sectional study using pooled PCR and serology. PLoS One 2012, 7:e29550.

2. Hay SI, Smith DL, Snow RW: Measuring malaria endemicity from intense to interrupted transmission. Lancet Infect Dis 2008, 8:369-378.

3. Yekutiel P: Problems of epidemiology in malaria eradication. Bull World Health Organ 1960, 22:669-683.

4. Wongsrichanalai C, Barcus MJ, Muth S, Sutamihardja A, Wernsdorfer WH: A review of malaria diagnostic tools: microscopy and rapid diagnostic test (RDT). Am J Trop Med Hyg 2007, 77:119-127.

5. McKenzie FE, Sirichaisinthop J, Miller RS, Gasser RA Jr, Wongsrichanalai C: Dependence of malaria detection and species diagnosis by microscopy on parasite density. Am J Trop Med Hyg 2003, 69:372-376.

6. Sousa-Figueiredo JC, Gamboa D, Pedro JM, Fancony C, Langa AJ, Magalhaes RJ, Stothard JR, Nery SV: Epidemiology of malaria, schistosomiasis, geohelminths, anemia and malnutrition in the context of a demographic surveillance system in northern Angola. PLOS One 2012, 7:e33189.

7. Kilian AH, Metzger WG, Mutschelknauss EJ, Kabagambe G, Langi P, Korte R, Von Sonnenburg F: Reliability of malaria microscopy in epidemiological studies: results of quality control. Trop Med Int Health 2000, 5:3-8.

8. Njama-Meya D, Kamya MR, Dorsey G: Asymptomatic parasitaemia as a risk factor for symptomatic malaria in a cohort of Ugandan children. Trop Med Int Health 2004, 9:862-868.

9. Keating J, Miller JM, Bennett A, Moonga HB, Eisele TP: Plasmodium falciparum parasite infection prevalence from a household survey in Zambia using microscopy and a rapid diagnostic test: implications for monitoring and evaluation. Acta Trop 2009, 112:277-282.

10. Endeshaw T, Gebre T, Ngondi J, Graves PM, Shargie EB, Ejigsemahu Y, Ayele B, Yohannes G, Teferi T, Messele A, Zerihun M, Genet A, Mosher AW, Emerson PM, Richards FO: Evaluation of light microscopy and rapid diagnostic test for the detection of malaria under operational field conditions: a household survey in Ethiopia. Malar J 2008, 7:118.

11. COSEP: Inquérito de Indicadores da Malária em Angola 2006/2007. Luanda Angola: Consultoria de Serviços, Estudos e Pesquisas - COSEP Lda. Consultadoria de Gestão e Administração em Saúde - Consaúde Lda., Macro International Inc; 2007.

12. Tanzania Commission for AIDS (TACAIDS) ZACZ, National Bureau of Statistics (NBS), Office of the Chief Government Statistician (OCGS), and Macro International Inc: Tanzania HIV/AIDS and Malaria Indicator Survey 2007-08. Dar es Salaam, Tanzania: TACAIDS, ZAC, NBS, OCGS, and Macro International Inc; 2008.

13. Nyan OJC, Manneh K, Jarjou E: Malaria Baseline Survey Final Report. Gambia: Malaria case management (MCM), Insecticide treated nets (ITNs), Intermittent preventive treatment (IPTp); 2009. 
14. Haque U, Ahmed SM, Hossain S, Huda M, Hossain A, Alam MS, Mondal D, Khan WA, Khalequzzaman M, Haque R: Malaria prevalence in endemic districts of Bangladesh. PLoS One 2009, 4:e6737

15. Hopkins H, Bebell L, Kambale W, Dokomajilar C, Rosenthal PJ, Dorsey G: Rapid diagnostic tests for malaria at sites of varying transmission intensity in Uganda. J Infect Dis 2008, 197:510-518.

16. Francis D, Gasasira A, Kigozi R, Kigozi S, Nasr S, Kamya MR, Dorsey G: Health facility-based malaria surveillance: the effects of age, area of residence and diagnostics on test positivity rates. Malar J 2012, 11:229.

17. Okell LC, Ghani AC, Lyons E, Drakeley CJ: Submicroscopic infection in Plasmodium falciparum-endemic populations: a systematic review and meta-analysis. J Infect Dis 2009, 200:1509-1517.

18. Kyabayinze DJ, Tibenderana JK, Odong GW, Rwakimari JB, Counihan H: Operational accuracy and comparative persistent antigenicity of HRP2 rapid diagnostic tests for Plasmodium falciparum malaria in a hyperendemic region of Uganda. Malar J 2008, 7:221.

19. Hopkins H, Kambale W, Kamya MR, Staedke SG, Dorsey G, Rosenthal PJ: Comparison of HRP2- and pLDH-based rapid diagnostic tests for malaria with longitudinal follow-up in Kampala, Uganda. Am J Trop Med Hyg 2007, 76:1092-1097.

20. Ishengoma DS, Francis F, Mmbando BP, Lusingu JP, Magistrado P, Alifrangis $M$, Theander TG, Bygbjerg IC, Lemnge MM: Accuracy of malaria rapid diagnostic tests in community studies and their impact on treatment of malaria in an area with declining malaria burden in north-eastern Tanzania. Malar J 2011, 10:176.

21. Koita OA, Doumbo OK, Ouattara A, Tall LK, Konare A, Diakite M, Diallo M, Sagara I, Masinde GL, Doumbo SN, Dolo A, Tounkara A, Traore I, Krogstad $D J$ : False-negative rapid diagnostic tests for malaria and deletion of the histidine-rich repeat region of the hrp2 gene. Am J Trop Med Hyg 2012, 86:194-198.

22. Luchavez J, Baker J, Alcantara S, Belizario V Jr, Cheng Q, McCarthy JS, Bell D: Laboratory demonstration of a prozone-like effect in HRP2-detecting malaria rapid diagnostic tests: implications for clinical management. Malar J 2011, 10:286.

23. Gamboa D, Ho MF, Bendezu J, Torres K, Chiodini PL, Barnwell JW, Incardona S, Perkins M, Bell D, McCarthy J, Cheng Q: A large proportion of P. falciparum isolates in the Amazon region of Peru lack pfhrp2 and pfhrp3: implications for malaria rapid diagnostic tests. PLoS One 2010, 5:e8091.

24. Maltha J, Gamboa D, Bendezu J, Sanchez L, Cnops L, Gillet P, Jacobs J: Rapid diagnostic tests for malaria diagnosis in the Peruvian Amazon: impact of pfhrp2 gene deletions and cross-reactions. PLoS One 2012, 7:e43094.

25. Gillet $P$, Scheirlinck A, Stokx J, De Weggheleire A, Chauque HS, Canhanga OD, Tadeu BT, Mosse CD, Tiago A, Mabunda S, Bruggeman C, Bottieau E, Jacobs J: Prozone in malaria rapid diagnostics tests: how many cases are missed? Malar J 2011, 10:166

26. WHO: Malaria Rapid Diagnosis: Making it Work. Meeting Report Regional Office for the Western Pacific. Geneva, Switzerland: World Health Organization; 2003

27. WHO: The role of laboratory diagnosis to support malaria disease management. Geneva, Switzerland: World Health Organization; 2004.

28. Swarthout TD, Counihan H, Senga RK, van den Broek I: Paracheck-Pf accuracy and recently treated Plasmodium falciparum infections: is there a risk of over-diagnosis? Malar J 2007, 6:58.

29. Chinkhumba J, Skarbinski J, Chilima B, Campbell C, Ewing V, San Joaquin M, Sande J, Ali D, Mathanga D: Comparative field performance and adherence to test results of four malaria rapid diagnostic tests among febrile patients more than five years of age in Blantyre Malawi. Malar J 2010, 9:209.

30. Batwala $V$, Magnussen $P$, Nuwaha F: Are rapid diagnostic tests more accurate in diagnosis of Plasmodium falciparum malaria compared to microscopy at rural health centres? Malar J 2010, 9:349.

31. Coleman RE, Sattabongkot J, Promstaporm S, Maneechai N, Tippayachai B, Kengluecha A, Rachapaew N, Zollner G, Miller RS, Vaughan JA, Thimasarn K, Khuntirat B: Comparison of PCR and microscopy for the detection of asymptomatic malaria in a Plasmodium falciparum/vivax endemic area in Thailand. Malar J 2006, 5:121.

32. Woyessa A, Deressa W, Ali A, Lindtjorn B: Evaluation of CareStart malaria $\mathrm{Pf} / \mathrm{Pv}$ combo test for Plasmodium falciparum and Plasmodium vivax malaria diagnosis in Butajira area, south-central Ethiopia. Malar J 2013, 12:218.

33. Tham JM, Lee SH, Tan TM, Ting RC, Kara UA: Detection and species determination of malaria parasites by PCR: comparison with microscopy and with ParaSight-F and ICT malaria Pf tests in a clinical environment. J Clin Microbiol 1999, 37:1269-1273.

34. Mens P, Spieker N, Omar S, Heijnen M, Schallig H, Kager PA: Is molecular biology the best alternative for diagnosis of malaria to microscopy? A comparison between microscopy, antigen detection and molecular tests in rural Kenya and urban Tanzania. Trop Med Int Health 2007, 12:238-244.

35. Snounou G, Viriyakosol S, Zhu XP, Jarra W, Pinheiro L, do Rosario VE, Thaithong S, Brown KN: High sensitivity of detection of human malaria parasites by the use of nested polymerase chain reaction. Mol Biochem Parasitol 1993, 61:315-320.

36. Johnston SP, Pieniazek NJ, Xayavong MV, Slemenda SB, Wilkins PP, Da Silva AJ: PCR as a confirmatory technique for laboratory diagnosis of malaria. J Clin Microbiol 2006, 44:1087-1089.

37. Mixson-Hayden T, Lucchi NW, Udhayakumar V: Evaluation of three PCRbased diagnostic assays for detecting mixed Plasmodium infection. BMC Res Notes 2010, 3:88.

38. Singh N, Shukla MM, Shukla MK, Mehra RK, Sharma S, Bharti PK, Singh MP, Singh A, Gunasekar A: Field and laboratory comparative evaluation of rapid malaria diagnostic tests versus traditional and molecular techniques in India. Malar J 2010, 9:191.

39. Gatti S, Gramegna M, Bisoffi Z, Raglio A, Gulletta M, Klersy C, Bruno A, Maserati R, Madama S, Scaglia M: A comparison of three diagnostic techniques for malaria: a rapid diagnostic test (NOW Malaria), PCR and microscopy. Ann Trop Med Parasitol 2007, 101:195-204.

40. Boonma P, Christensen PR, Suwanarusk R, Price RN, Russell B, Lek-Uthai U: Comparison of three molecular methods for the detection and speciation of Plasmodium vivax and Plasmodium falciparum. Malar J 2007, 6:124.

41. Costa MJ, Rosário E, Langa A, António G, Bendriss A, Nery SV: Setting up a Demographic Surveillance System in the Dande Municipality Angola. African Population Studies 2012, 26(2):133-146.

42. Consultoria de Serviços EeP-CL: Consultadoria de Gestão e Administração em Saúde - Consaúde Lda., Macro International Inc. Luanda - Angola: Inquérito de Indicadores de Malária em Angola 2011; 2011.

43. Fançony C, Gamboa D, Sebastião Y, Hallett R, Sutherland C, Sousa-Figueiredo JC, Nery SV: Various pfcrt and pfmdr1 genotypes of Plasmodium falciparum cocirculate with $P$. malariae, $P$. ovale spp., and $P$. vivax in northern Angola. Antimicrob Agents Chemother 2012, 56:5271-5277.

44. WHO: Basic Laboratory Methods in Medical Parasitology. Geneva; 1991.

45. WHO: Malaria Microscopy Quality Assurance Manual: Version 1. Geneva: World Health Organization; 2009.

46. Calderaro A, Piccolo G, Perandin F, Gorrini C, Peruzzi S, Zuelli C, Ricci L, Manca N, Dettori G, Chezzi C, Snounou G: Genetic polymorphisms influence Plasmodium ovale PCR detection accuracy. J Clin Microbio/ 2007, 45:1624-1627

47. Kosinski AS: A weighted generalized score statistic for comparison of predictive values of diagnostic tests. Stat Med 2013, 32:964-977.

48. Teirlinck AC, McCall MB, Roestenberg M, Scholzen A, Woestenenk R, De Mast Q, van der Ven AJ, Hermsen CC, Luty AJ, Sauerwein RW: Longevity and composition of cellular immune responses following experimental Plasmodium falciparum malaria infection in humans. PLOS Pathog 2011, 7:e1002389.

49. Marsh K, Kinyanjui S: Immune effector mechanisms in malaria. Parasite Immunol 2006, 28:51-60.

50. Payne D: Use and limitations of light microscopy for diagnosing malaria at the primary health care level. Bull World Health Organ 1988, 66:621-626.

51. Houze S, Hubert V, Le Pessec G, Le Bras J, Clain J: Combined deletions of pfhrp2 and pfhrp3 genes result in Plasmodium falciparum malaria falsenegative rapid diagnostic test. J Clin Microbiol 2011, 49:2694-2696.

52. Maltha J, Gillet $P$, Jacobs J: Malaria rapid diagnostic tests in endemic settings. Clin Microbiol Infect 2013, 19:399-407.

53. Bell DR, Wilson DW, Martin LB: False-positive results of a Plasmodium falciparum histidine-rich protein 2-detecting malaria rapid diagnostic test due to high sensitivity in a community with fluctuating low parasite density. Am J Trop Med Hyg 2005, 73:199-203.

54. Coleman RE, Maneechai N, Rachaphaew N, Kumpitak C, Miller RS, Soyseng $V$, Thimasarn K, Sattabongkot J: Comparison of field and expert laboratory microscopy for active surveillance for asymptomatic Plasmodium falciparum and Plasmodium vivax in western Thailand. Am J Trop Med Hyg 2002, 67:141-144.

55. Laferi $\mathrm{H}$, Kandel K, Pichler $\mathrm{H}$ : False positive dipstick test for malaria. N Engl J Med 1997, 337:1635-1636. 
56. Bartoloni A, Sabatinelli G, Benucci M: Performance of two rapid tests for Plasmodium falciparum malaria in patients with rheumatoid factors. N Engl I Med 1998, 338:1075.

57. Gillet P, Mumba Ngoyi D, Lukuka A, Kande V, Atua B, van Griensven J, Muyembe JJ, Jacobs J, Lejon V: False positivity of non-targeted infections in malaria rapid diagnostic tests: the case of human african trypanosomiasis. PLoS Negl Trop Dis 2013, 7:e2180.

58. Hsiang MS, Lin M, Dokomajilar C, Kemere J, Pilcher CD, Dorsey G, Greenhouse B: PCR-based pooling of dried blood spots for detection of malaria parasites: optimization and application to a cohort of Ugandan children. J Clin Microbiol 2010, 48:3539-3543.

59. Moges B, Amare B, Belyhun Y, Tekeste Z, Gizachew M, Workineh M, Gebrehiwot A, Woldeyohannes D, Mulu A, Kassu A: Comparison of CareStart HRP2/pLDH COMBO rapid malaria test with light microscopy in north-west Ethiopia. Malar J 2012, 11:234.

doi:10.1186/1475-2875-12-284

Cite this article as: Fançony et al:: Performance of microscopy and RDTs in the context of a malaria prevalence survey in Angola: a comparison using PCR as the gold standard. Malaria Journal 2013 12:284.

\section{Submit your next manuscript to BioMed Central and take full advantage of:}

- Convenient online submission

- Thorough peer review

- No space constraints or color figure charges

- Immediate publication on acceptance

- Inclusion in PubMed, CAS, Scopus and Google Scholar

- Research which is freely available for redistribution 